\title{
Dentistry-The Three Act Play
}

\section{Marc B. Cooper*}

Department of Periodontics, University of Washington School of Graduate Dentistry, USA

"More relative than this-the play's the thing."

\section{-William Shakespeare; Hamlet}

Dentistry can be looked at as a three act play. Act 1 is the past, Act 2 is the present and Act 3 is the future. The past is fee-for-service solo practice. This past of solo practice is deeply embedded in the mindset and culture of dentists. Nearly all teachers, pundits, consultants, journals, and CE programs are resolutely anchored to the past and committed to preserving this past. But what if this past is not a determinant of the future?

Act 2 is the present. Actions, decisions, choices all occur in the present. There are no actions, decisions or choices made in the past since it is over and done with. And there are no actions, decisions or choices made in the future since it has not yet happened. But what determines the actions, decisions and choices made in the present?

Act 2 is basically determined by what will occur in Act 3 . The present is determined by the future. Now surely Act 1 , the past, must have some linkage to Act 3, the future. Act 3 can't be completely discontinuous from Act 1, but it doesn't have to replicate it or be a direct extension of past. In fact, in most great plays, Act 3 is very unlike what might be predicted from Act 1.

An example might be pay phones. That would be the past, Act 1 . Act 3, the future would be cell phones. What ATT and Verizon did in the present, Act 2, allowed them to dominate the industry. They didn't try to keep the past going. They saw the future, made decisions and took actions in the present that would allow them dominate the future of cell phones.

When you study the business literature about successful companies, all those in some way foresaw a future, made decisions and took actions that enabled them to succeed in that future. Another example is Apple which saw that personal computing was the future and made their choices based on that future. Although computing at the time was dominated by large frame computers (IBM), Apple anticipated personal computing as the future. Was the future of personal computing a guaranteed future? No. But it was a future they believed was possible and would most likely occur.

This story has repeated itself many times; Intel, Southwest, Amazon, Starbucks, Zappos, Facebook, Twitter. And it is also apparent in dentistry with Heartland, Pacific, American Dental Partners, for example.

The future determines the choices and actions in the present.

Dentistry is clearly moving into a different future than the past. Based on the evidence and trends, my view is that the majority of dentists in solo private practice, whose models and cultures are based on the past, will find themselves in the same predicament as the pay phone manufacturers. You can make the best payphone ever made, but payphones didn't fit the future of telecommunications. You can also have the best solo practice on the planet, but if doesn't fit the future, it won't matter (Figure 1).

Additional trends include:

-National dental expenditures have gone flat and remain flat since 2008.
-Dentists incomes declined in 2007 and have gone flat since.

-Per patient dental expenditures have been flat since 2009 and remain flat.

-Average annual growth rate of overall dental expenditures has tanked.

-Immergence of midlevel providers.

-Equity partners and venture capitalists heavily investing in the dental space.

-Seventy percent of patients seen in dental offices have some form of dental plan.

-Ninety-two percent of dentists take some form of dental plan.

-Government mandates laws and programs.

-Snowballing expenses of owning and operating a dental practice.

When you connect the dots from the trends, the future is obvious. Look no further than medicine, pharmacy and optical to see what occurred with independent solo practice when the same forces were at play. The probable future is managed group practice.

\section{Act 3 of Dentistry-The Future}

Since the future has not yet happened, anything is possible. But if you study trends and patterns, you have some ability to forecast what might occur in the future.

The trend is a steady and continuous decrease in the number of solo practices, and this trend is predicted to continue. Practice values will fall so the negotiable value of solo practices will fall as well. Corporate competitors, fewer and fewer qualified buyers, government mandates and laws, burdensome debt-load of graduates, increasing restrictions on financing by banks, fewer dentists wanting to be owners, are just some of the pressures driving this decrease in value of solo practice.

\section{The Tipping Point}

The 'tipping point,' as established by author, Malcolm Gladwell, is when a product or service attains between $15-19 \%$ of market penetration; it then becomes adopted by the majority. Managed Group Practice has now exceeded $17 \%$ of the dentistry delivered in the country, which means it has surpassed the tipping point [1].

Millions upon millions of dollars are being poured into the formation and operation of Managed Group Practice. Why? According to Goldman-Sachs [2], "Such investments are paying off for private

*Corresponding author: Dr. Marc B. Cooper, The Mastery Company, 12940 NW Marina Way, Houseboat \#6, Portland OR 97231, USA, Tel: 503289 1191; E-mail: mcooper@masterycompany.com

Received March 24, 2015; Accepted April 16, 2015; Published April 21, 2015

Citation: Cooper MB (2015) Dentistry-The Three Act Play. Dentistry 5: 298. doi:10.4172/2161-1122.1000298

Copyright: (c) 2015 Cooper MB. This is an open-access article distributed under the terms of the Creative Commons Attribution License, which permits unrestricted use, distribution, and reproduction in any medium, provided the original author and source are credited. 


\section{Percentage of Solo Practices in the U.S.}

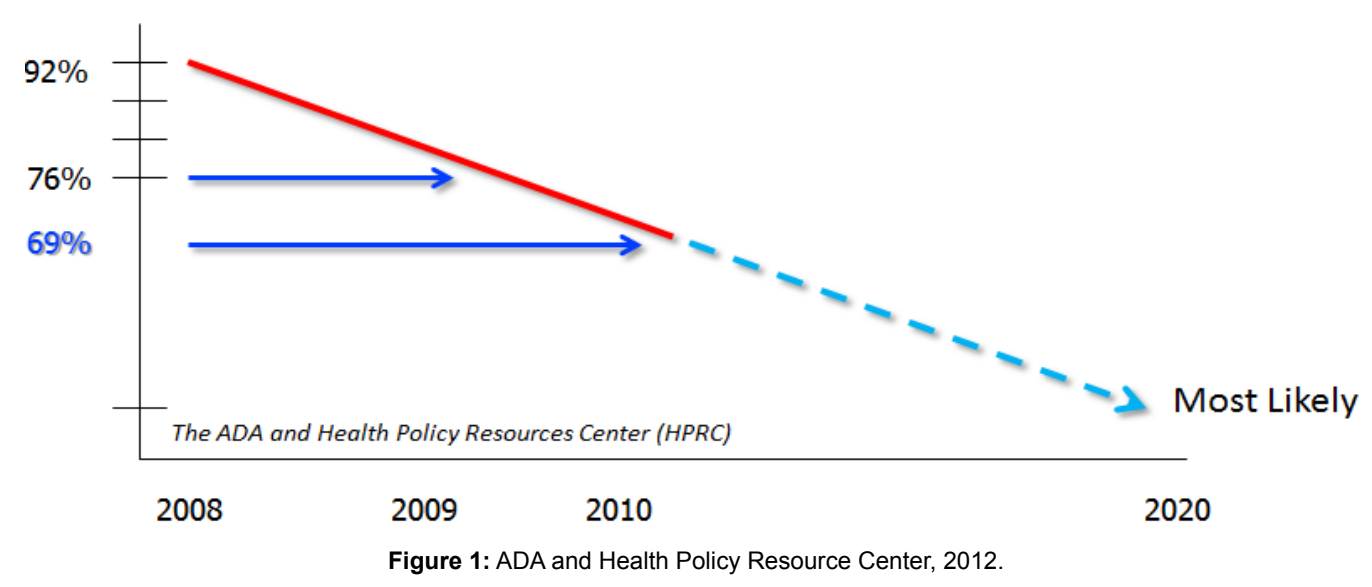

equity firms; a Sageworks analysis found that DPM investments generated the highest return on equity of the industries they examined."

Although the dentists, their associations and academies, the pundits and consultants, and the brokers all claim that solo practice will not be vanquished, given the trends, the rapid growth of managed groups, the decreasing number of solo practice, it ought to be clear that are inaccurate in their predictions.

\section{Managed Group Practice}

Act 3, the future, will be more than likely be dominated by Managed Group Practice. There are many different breeds of Managed Group Practice. There are groups that are internally managed and some that are externally managed by a Managed Service Organization (MSO). There are small, locally managed group practices as well as very large, well-established national groups. But no matter which model they employ, nearly all are experiencing strong growth and rapid expansion.

Managed group practices can do what solo practice cannot do given their economies of scale and bargaining leverage. Managed group practices can hire season's senior executives, such as Human
Resources, Chief operating officers, Chief financial officers and facility management. They can build a call center. Manage group practice is far better than solo practice at managing costs, decreasing expenses, enhancing access, negotiations with $3^{\text {rd }}$ parties and vendors, securing and retaining associates, providing strong benefit packages for staff, to providing dentists with a solid exit strategy, developing and utilizing quality assurance including peer review, and the list goes on.

Dentists should ask themselves about the appropriate actions they need to take in the present, so they can compete in the future. Dentists in solo practice need to realize that Act 1, solo practice, is done, over, finished. Act 2, the present is playing out now. And Act 3, although has different futures that are possible, the one future that seems most likely is managed group practice.

\section{References}

1. Nuss E (2015) Uncovering the truth about managed practices: Beat them or join them? Dental Economics 105: 2.

2. Becker S, Bushee MM, Cockrell G, Saran JC, Carnell H, et al. (2014) The Top Areas in Healthcare for Private Equity Investment in 2014. Becker's Hospital Review. 